\title{
Rumpukompostorista hevostallien lantalogistiikan ratkaisu?
}

\author{
Riina Huttunen ${ }^{1,2}$; Katriina Pylkkänen ${ }^{1}$; Kati Partanen ${ }^{1}$; Teija Rantala ${ }^{1}$; Niina Puumalainen ${ }^{2}$. \\ 1) Savonia-ammattikorkeakoulu, PL 72, 74101 Iisalmi, etunimi.sukunimi@ savonia.fi \\ 2)Ylä-Savon ammattiopisto, PL 30, 74101 Iisalmi etunimi.sukunimi@ysao.fi
}

\begin{abstract}
Tiivistelmä
Lannankäsittely on yksi suurimmista hevostallien ympäristöhaasteista. Varsinkin taajamien lähellä hevosten lantalogistiikka tuottaa ongelmia, sillä kuivalannan käyttö peltoviljelyssä ei aina onnistu ja poiskuljettaminen on kallista. Ylä-Savon Ammattiopiston Hingunniemen koulutila tutkii rumpukompostoinnin hyödyntämistä hevosen lannan käsittelyssä. Kompostointiprosessissa muodostuva hukkalämpö otetaan talteen ja lämpöenergia hyödynnetään tallin käyttövesien ja lattioiden lämmitykseen. Kuivikevalinta vaikuttaa hevosen lannan jatkokäyttöön ja tallien ympäristökuormitukseen merkittävästi. Kasvipohjaiset kuivikkeet sopivat hyvin lannan seassa lannoitteeksi, mutta puupohjaisten kuivikkeiden käyttö laskee kuivalannan lannoitusarvoa. Hevosen kuivikelannan ongelmia ovat sen varastoinnin vaatima iso tilantarve, liukoisen typen haihtuminen varastoinnin aikana ammoniakkina sekä puupohjaisten kuivikkeiden hidas kompostoituminen.

Rumpukompostoinnissa kompostointi toteutetaan hallitusti sille erityisesti suunnitellussa tilassa. Lanta käsitellään sylinterin muotoisessa putkessa, joka pyörii vaaka-akselinsa ympäri. Lantamassa ilmastuu prosessin aikana ja kompostoituminen tapahtuu nopeasti ja tasaisesti. Keskimääräinen kompostoitumisaika on kymmenen päivää. Rumpukompostoinnin jälkeen lanta puretaan välivarastoon jälkikompostoitumaan.

Rumpukompostoinnin aikana lämpö rummussa nousee n. $50-60{ }^{\circ} \mathrm{C}$ :een. Perusmateriaalin hiilityppisuhteen tulisi olla lähellä 30/1. Hingunniemen koulutilalla muodostuvalla turvekuivitetulla hevosenlannalla päästään lähelle tätä tavoitetta. Tavoitteena on tyhjentää ja täyttää rumpua niin, että täyttöaste pysyy $50-60 \%$ :ssa. Kompostointiprosessissa syntyvä poistoilma on n. $40^{\circ} \mathrm{C}$ vesihöyryä.

Prosessin poistoilma voidaan hyödyntää keräämällä se talteen ja siirtämällä esimerkiksi tallin pesuvesien ja lattioiden lämmitykseen lämpöpumppujärjestelmällä. Lämpöpumpun tehokkuutta mitataan lämpökertoimella, joka ilmaisee, paljonko pumppu tuottaa lämpöä sen käyttämään sähköenergiaan verrattuna.

Rumpukompostori ja lämmön talteenotto on ollut Hingunniemessä käytössä tammikuusta 2013 alkaen. Ensimmäisen seitsemän kuukauden aikana lantaa kompostoitiin noin $400 \mathrm{~m}^{3}$ ja lämpöä otettiin talteen 16000 kW. Kokemukset rumpukompostorista lannan käsittelymenetelmänä ovat positiiviset. Lannan käsittely on ympäristön kannalta hallittua ja kompostointiprosessista muodostuva hukkalämpö on hyödynnetty ravitallissa lämpöenergiana käyttövesien lämmitykseen sekä lattialämmitykseen. Lopputuotoksena syntyy pelloille patogeenivapaata maanparannusainetta. Kestävä talliympäristö -hankkeen pitkäaikaisena tavoitteena on ollut energiaomavaraisuuden kasvattaminen sekä energiatehokkuuden kehittäminen hevostalleilla.
\end{abstract}

\author{
Asiasanat \\ kompostointi, hevosenlanta, hevostalous, kestävä kehitys
}




\section{Johdanto}

Hevosten määrän kasvaessa kiinnitetään yhä enemmän huomiota ympäristöasioihin myös hevossektorilla Suomessa. Hevosala itsessään ei ole kovinkaan merkittävä ympäristön kuormittaja maailman ja Suomen laajuisiin ympäristöongelmiin verrattuna, mutta paikallisesti kuormituspiikki voi olla huomattava. Ennen kaikkea alan imagon kannalta on entistä tärkeämpää kiinnittää huomiota ympäristöasioihin ja talliympäristön viihtyvyyteen. Hyvin usein ympäristön viihtyvyys paranee juuri ympäristöasioihin panostamalla. Talliyrittäjät kokevat ympäristöasiat helposti hankalana ja normaalia yritystoimintaa kuormittavana asiana. Lainsäädäntö koetaan haastavaksi ja koko ajan kiristyväksi.

Ylä-Savon ammattiopiston hevostalouden koulutusyksikkö Kiuruvedellä tarjoaa monipuolista hevosalan koulutusta. Opiskelijoita hakeutuu opiskelemaan eri puolelta Suomea. Erilaisten kurssien, kilpailuiden ja tapahtumien johdosta Hingunniemessä käy runsaasti ulkopuolisia vierailijoita. Oppilaitoksen koulutilaa voidaan pitää nykyaikaisena hevosalan mallitilana, jonne hakeudutaan saamaan alan viimeisintä tietoa ja osaamista. Koulutila sijaitsee niemessä ja on rajallisen kokonsa, ympäristön ja erityisesti vesiensuojelun kannalta haastavalla paikalla. Hingunniemessä on haluttu panostaa ympäristöasioihin.

Hingunniemeen on peruskorjattu ja laajennettu ravitalli vuosien 2011 - 2012 aikana Ylä-Savon koulutuskuntayhtymän investointisuunnitelman mukaisesti. Tavoitteena oli investoinnin kehittäminen siten, että rakennettavassa tallissa ympäristöasiat ovat hallinnassa. Kestävä talliympäristö - projektin tavoitteena on ympäristökuormituksen kokonaisvaltainen minimoiminen sekä energiatehokkuus. Projektissa haetaan ratkaisuja vesivarojen kestävän käytön edistämiseen, jätteiden uudelleen käyttöön ja tehostamiseen sekä ympäristökuormituksen vähentämiseen jätevesien käsittelyä tehostamalla. Tavoitteena on lannan käytettävyyden selvittäminen siten, että se on ympäristön kannata hallittua ja hyödynnettävyydeltään tehokkaampaa. Selvitettävänä on lannan lämmön talteenoton sekä vedenkierrätyksen yhteensovittaminen sekä sen aikaansaamat mahdollisuudet. Hallittu ympäristöasioiden hoito säästää sekä ympäristöä että rahaa. Hevosen lanta luetaan jätteeksi ja se tulisi hyödyntää ensisijaisesti kierrättämällä se takaisin lannoitteeksi. Laskennallisesti yksi hevonen tuottaa lantaa $12 \mathrm{~m}^{3}$ ja poni tai alle vuoden ikäinen varsa $8 \mathrm{~m}^{3}$ vuodessa. Jätelain mukaisesti kaikessa toiminnassa on pyrittävä siihen, että jätteestä ei koidu merkityksellistä vaaraa tai haittaa ympäristölle eikä terveydelle.

\section{Hevosen lannan kompostointi}

Kompostoinnissa pieneliöt toimivat hapellisissa olosuhteissa. Pieneliöillä tarkoitetaan mikrobeja, kuten bakteereita, sieniä, sädesieniä sekä maaperän eläimiä kuten lieroja, jotka saavat energiaa hajottamalla eloperäistä jätettä. Pieneliöt hajottavat eloperäisen jätteen humukseksi, mikä on multaa muistuttava maanparannusaine. Humuksen lisäksi kompostointiprosessissa syntyy lämpöenergiaa, hiilidioksidia, vettä sekä ravinnesuoloja eli kasvien tarvitsemia kivennäisaineita. Mikrobitoiminnan ansiosta lämpötila kohoaa ulkoilman lämpötilaa korkeammaksi, mikä nopeuttaa kemiallisia ja biologisia reaktioita massassa ja siten orgaanisen aineksen hajoaminen on nopeampaa, jos verrattaisiin Suomen luonnonoloissa tapahtuvaan hitaaseen maatumiseen. Kompostointi on jätteenkäsittelymenetelmän lisäksi siis keino tuottaa maahan orgaanista aineista ja ravinteita korvaavia lannoitteita sekä maanparannusaineita.

Kompostointi vähentää ravinteiden liukoisuutta ja siten lieventää ravinteiden vesistöjen kuormitusta. Kompostista tapahtuu kuitenkin lähes aina ravinnehävikkejä jos ei muuten niin haihtumalla. Kompostoinnin aikaiset typen tappiot voivat olla suuriakin ja suurin hävikki tapahtuu prosessin aktiivisen mikrobitoiminnan alkuvaiheessa. Ammoniakin haihtumista edistää korkea lämpötila, pH ja hyvä ilmavuus. Ammoniakkina haihtuvan typen määrään vaikuttaa kompostoituvan aineksen hiili/typpisuhde. Käytännöllisin ja tehokkain keino vähentää typen hävikkiä on lisätä hiilipitoisia aineita kompostin lähtöaineisiin, jolloin mikroorganismit tarvitsevat enemmän typpeä voimistuneen hiiliyhdisteiden hajotuksen seurauksena juuri ammoniakin haihtumisen alttiissa vaiheessa. Toinen vaihtoehto on imeyttää ammoniakki aineeseen jolla vahva taipumus sitoa ammoniumioneja tai ammoniakkia. Kattamattomassa kompostissa voi jälkikypsytyksen aikana tapahtua typen hävikkiä jos nitriitti liukenee sadeveden mukana.

Hevosen lanta kompostoituu nopeasti, mutta käytettyjen kuivikemateriaalien kompostointinopeus vaihtelee suuresti. Huonoiten kompostoituvat puupohjaiset kuivikkeet, kuten sahanpuru ja kutterinlastu. Lannoitearvoltaan turvelanta on selvästi kutterinpurulantaa parempi. Kompostoimattomana puupohjaiset kuivikkeet sitovat typpeä maaperästä hajotessaan, tästä syystä puupohjainen kuivike heikentää lannan lannoitusarvoa. 
Kompostoinnin edut:

- Parantaa lannan hygieenistä laatua tuhoamalla rikkakasvin siemeniä, loisia sekä kärpästen munia

- Vähentää hajuhaittoja

- Parantaa lannan mikrobiologisia, kemiallisia sekä fysikaalisia ominaisuuksia tasaamalla pH:ta, edistämällä hyödyllisten mikrobien ja bakteerien kasvua sekä stabiloi ravinteet

- Suurin hyöty edellä mainittujen johdosta on lannan arvon nousu maanparannusaineena ja menekin parantuminen puutarhoissa sekä peltoviljelyssä.

Rumpukompostorilla kompostointi toteutetaan hallitusti sille erityisesti suunnittelussa tilassa. Lanta käsitellään sylinterin muotoisessa putkessa, joka pyörii vaaka-akselinsa ympäri. Kompostorissa lantamassa ilmastuu ja sillä tavalla kompostoituu nopeammin ja saa aikaan tasaisen ja nopean lopputuloksen.

Hevosen lanta koostuu ulosteen lisäksi kuivikkeista ja ylijäämärehuista. Valtaosa lantamäärästä, noin $50-80 \%$ on kuiviketta. Hevosenlannan kosteuspitoisuus vaihtelee kuivikkeen mukaan noin $60-70 \%$ välillä, jolloin puolestaan kuiva-ainepitoisuus on noin $30-40 \%$. Kuivikkeen tyypillä ei ole kosteuspitoisuuteen suurta merkitystä, koska lannassa oleva neste imeytyy joka tapauksessa kuivikkeeseen. Käytännössä kuitenkin turve imee jonkin verran enemmän kosteutta itseensä kuin puru. Kuivikkeiden osuus lantamäärästä riippuu kuivikevalinnan lisäksi karsinan siivoustekniikasta. Kiinteä uloste koostuu suolen mikrobimassasta sekä sulamattomien rehujen aineksista. Kiinteässä ulosteessa saattaa myös olla loiseläinten munia, rikkakasvien siemeniä sekä lääkejäämiä. Kuivikkeeseen sitoutunut virtsa on vettä sekä verenkierrosta poistuneista liukoisia yhdisteitä.

Hevostallin kuivikevalintaan vaikuttavat useat eri tekijät:

- saatavuus

- kuivikkeen kulutus

- ammoniakin sitomiskyky

- nesteen imukyky

- pölyisyys

- mikrobiologinen laatu

- käyttäjän tottumus ja mieltymys

- muut käyttöominaisuudet

- vaikutus lannan kompostoitumiseen

- vaikutus lannan lannoitusarvoon

Hevostallien kuivikevalinta on merkittävä tekijä tallien ympäristökuormituksen sekä lannan jatkokäytettävyyden kannalta. Kasvipohjaisia kuivikkeita (turve, olki, pellava, hamppu) voidaan käyttää lannoitteeksi, maanparannusaineeksi sekä viherrakentamiseen. Puupohjaisten kuivikkeiden (kutteri, sahanpuru, sanomalehtipaperi) jatkohyödyntäminen sellaisenaan on hankalaa. Käyttökohteiksi tulevat kysymykseen lähinnä täyttömaa tai polttaminen energiaksi.

Valtioneuvoston asetus jätteen polttamisesta säätelee hevosen lannan polttamista. Polttolaitoksen sekä sen päästöjen tiukat vaatimukset tekevät polttamisen kannattamattomaksi. Verrattaessa pelkkien kuivikkeiden sekä lannan poltto-ominaisuuksia, huomataan että lanta on huomattavasti kosteampaa kuin pelkät kuivikkeet. Korkea kosteuspitoisuus vaikuttaa merkittävästi myös lannan teholliseen lämpöarvoon.

\section{Aineisto ja menetelmät}

Kvalitatiivisen eli laadullisen tutkimuksen ominaispiirteiden mukaisesti tutkimus on ollut kokonaisvaltaista tiedon hankintaa ja aineistoa on kerätty luonnollisista todellisista tilanteista. Tutkimussuunnitelma muotoutui tutkimuksen edetessä. On tyypillistä, että ihmiset asettavat kysymyksiä ja tulkitsevat asioita omasta näkökulmastaan ja sen hetkisellä ymmärryksellä, mikä heillä on. Laadullisen tutkimuksen lähtökohtana on todellisen elämän kuvaaminen mahdollisimman kokonaisvaltaisesti. Ihmistä suositaan tiedon keruun instrumenttina. Tutkija luottaa enemmän omiin havaintoihin kuin mittausvälineillä tuotettuihin tietoihin. Tutkimuksessa käytetään induktiivista analyysiä eli tutkijan tavoitteena on paljastaa tutkittavasta asiasta odottamattomia seikkoja. Tästä syystä lähtökohtana ei ole teorian tai hypoteesin testaaminen vaan aineiston monitahoinen ja yksityiskohtainen tarkastelu.

Metodia valitessa suositaan sellaisia, joissa tutkittavien näkökulmat ja "ääni” tulevat kuulluksi. Tässä tutkimuksessa tutkimus pohjautuu tapaustutkimukseen. Tapaustutkimuksen avulla on tuotettu yksityiskohtaista, intensiivistä tietoa yksittäisestä tapauksesta tai pienestä joukosta toisiinsa suhteessa olevista tapauksista. Tyypillisessä tapaustutkimuksessa valitaan yksittäinen tapaus, tilanne tai joukko tapauksia. Tässä tapauksessa kysymyksessä Ylä-Savon koulutuskuntayhtymän, Kiuruveden toimipisteen 
Hingunniemen ravitallin peruskorjauksen ja laajennuksen yhteyteen kiinteästi nivoutuva Kestävä talliympäristö -projekti ja siinä kehitetyt ratkaisumallit. Tapaustutkimuksen mukaisesti yksittäistapausta tutkitaan luonnollisessa tilanteessa yhteydessä ympäristöönsä, josta yksittäistapaus on osa. Aineistoja kerätään useita metodeja käyttämällä, muun muassa havainnoimalla, haastattelemalla ja dokumentteja tutkimalla. Tavoitteena on tyypillisimmin ilmiöiden kuvailu.

\section{Tulokset ja tulosten tarkastelu}

Hingunniemen koulutilan tallien lanta käsitellään kuivikelantana, lukuun ottamatta pihaton lanta joka on kuivikepohjalla. Pääasiallisesti käytettävä kuivike on turve. Lannan varastointitilavuutta koulutilalla on käytettävissä noin $900 \mathrm{~m}^{3}$. Laskennallisesti kuivikelantaa muodostuu 12 kuukaudessa $936 \mathrm{~m}^{3}$. Tähän laskentaan ei ole huomioitu laidunaikaa, jolla lantalan laskennallista tilavuutta voidaan pienentää. Kaikki hevosten lanta käsittelemään rumpukompostorilla, joka sijaitsee ravitallin yhteydessä olevassa erillisessä tilassa.

Rumpukompostorissa käsitellään noin 20 tuhatta kiloa eli noin $40 \mathrm{~m}^{3}$ hevosenlantaa viikossa. Lanta syötetään rumpukompostorin sisään hydraulisella kuljettimella ja puretaan välivarastoon purkuruuvilla. Kaikkien tallien, pihaton sekä tarhojen lanta siirretään kompostoinnin jälkeen $690 \mathrm{~m}^{3}$ käsitellyn lannan varastoon eli niin sanottuun jälkikypsytysvarastoon. Tällä hetkellä kompostoitu lanta eli maanparannusaine levitetään pääasiassa koulutilan omille pelloille. Osa lannasta luovutetaan lannanluovutussopimusten tehneille tiloille.

Kompostoinnissa mikrobit muuttavat orgaanisen aineksen hiilidioksidiksi, lämmöksi sekä humukseksi. Prosessissa syntyvä poistoilma on noin $40{ }^{\circ} \mathrm{C}$ lämmintä vesihöyryä. Kompostointirumpua voidaan sanoa suureksi eristetyksi prosessisäiliöksi. Syöttöruuvi syöttää lannan rumpuun ja samalla tyhjennysruuvi tyhjentää kompostoidun lannan ulos rummun takaosasta. Prosessin aikana mikrobitoiminnan ansiosta lämpö nousee rummussa 50-60 ${ }^{\circ} \mathrm{C}$ :een. Tavoiteltaessa mikrobitoiminnan kannalta optimaalisia olosuhteita säädetään ulostuloilman ja prosessin lämpötiloja valvomalla.

Kompostorissa on kaksi puhallinta, toinen on sisääntulon lopussa ja toinen rummun takaosassa ulostulossa. Kompostori on varustettu myös sisäisellä ilmastointijärjestelmällä happipitoisuuden kontrolloimiseksi. Kompressori varmistaa ilmamäärän koko ilmastoinnille. Prosessia valvotaan manuaalisesti tehtyjen tarkistusten kautta. Perusmateriaalin hiili/typpisuhteen täytyisi olla lähellä 30/1 ja kosteusasteen $\sim 50 \%$ DS. Kompostorin tehokkuuteen vaikuttaa suoraan sille syötetty kuorma. Päivittäin tarkistetaan rumpuun syötetyn lannan määrä sekä pidetään tarkkaa kirjaa syötetyistä materiaaleista, käyntitunneista sekä lämpötiloista. Optimaalinen tilanne on se, että rumpua syötetään ja tyhjennetään täyttöasteen pysyessä $50-60 \%$ :ssa.

Lämpöpumpputekniikan avulla prosessista muodostuva poistoilma hyödynnetään keräämällä se talteen ja siirretään tallin pesuvesien sekä lattioiden lämmittämiseen. Lämpöpumppujärjestelmä muodostuu lämmönkeruuputkistosta, sen sisällä kiertävästä liuoksesta sekä lämpöpumppuyksiköstä. Maalämpöpumppuyksikkö koostuu kompressorista, höyrystimestä, lauhduttimesta ja pumpun sisällä kiertävästä kylmäaineesta. Lämpöpumpun tehokkuutta mitataan lämpökertoimella. Se kertoo kuinka paljon pumppu pystyy tuottamaan lämpöä sen käyttämään sähköenergiaan verrattuna eli kuinka moninkertaisesti laite pystyy tuottamaan lämpöä kuluttamallaan sähköllä tietyssä olosuhteessa.

Hingunniemen laitteiston lämpöpumpun lämpökerroin on 4,0 - 4,5. Lämpöpumpun lämpökerroin on sitä parempi, mitä pienempi on lämmönlähteen eli tässä tapauksessa kompostointiprosessista muodostuvan poistolämmön ja lämpöä luovuttavan putkiston välinen lämpötilaero. Yleisin lämpöpumpputekniikan sovellus on jääkaappi, jossa lämpöä siirretään jääkaapista sitä ympäröivään huonetilaan. Kompostointiprosessista muodostuva poistolämpö toimii lämpöpumpun avulla samalla tavalla eli lämpö siirtyy lämmitysjärjestelmään sekä lämpimään käyttöveteen.

Hingunniemen ravitallin yhteyteen on rakennettu erillinen kompostorihuone, missä sijaitsee rumpukompostori. Rumpukompostorissa käsitellään kaikkien tallien eli yhteensä noin 79 hevosen kuivikelanta. Kompostointiprosessissa ei käytetä kuivitetun lannan lisäksi muita seosaineita. Lanta tuodaan ravitallista suoraan kottikärryillä ja muista talleista pienkuormaajalla hydraulikuljettimelle, joka syöttää lantaa tasaisesti kompostorille. Toiminta-aika on ajastettavissa. Rummun pyöriessä lanta siirtyy kompostorin sisällä eteenpäin.

Kompostoitunut lanta tulee ulos rummun toisesta päästä ruuvikuljettimella käsittelyn lannan välivarastoon. Välivarastosta kompostoitu lanta kuormataan kauhakuormaajalla traktorin peräkärryyn ja 
ajetaan käsitellyn lannan varastoon. Vaihtoehtoisesti peräkärry on valmiina purkuruuvin alla ja kuorma täytyttyään ajetaan käsitellyn lannan varastoon jälkikompostoitumaan.

Rumpukompostori ja lämmön talteenotto on ollut Hingunniemessä käytössä tammikuusta 2013 alkaen. Ensimmäisen seitsemän kuukauden aikana lantaa kompostoitiin noin $400 \mathrm{~m}^{3}$ ja lämpöä otettiin talteen 16000 kW. Kokemukset rumpukompostorista lannan käsittelymenetelmänä ovat positiiviset. Lannan käsittely on ympäristön kannalta hallittua ja kompostointiprosessista muodostuva hukkalämpö on hyödynnetty ravitallissa lämpöenergiana käyttövesien lämmitykseen sekä lattialämmitykseen. Lopputuotoksena syntyy pelloille patogeenivapaata maanparannusainetta.

\section{Johtopäätökset}

Toimimaton lantaketju on hevostallien merkittävin ympäristöhaaste. Sitä pidetään myös ongelmana talliyrittäjälle. Käytettävien kuivikkeiden valinnalla nähdään olevan merkitystä lantaketjun alkupäässä toimivan ketjun aikaansaamiseksi. Lannan käsittelytavalla on merkitystä jo senkin takia, että lanta luetaan jätteeksi. Hingunniemen esimerkkitapauksessa lannan kuljetuskustannukset eivät ole ongelma, mutta varsinkin taajamien läheisyydessä se voi olla huomattava kuluerä tallille. On talleja, joista lanta on jouduttu ajamaan kaatopaikalle. Toukokuussa 2012 uudistunut jätelaki voi siten aiheuttaa ongelmia. Kaikki kaatopaikat eivät enää ota lantaa vastaan, mikäli ne eivät käsittele sitä kompostoimalla. Lantaketjun toiminnallisuuden kehittäminen sekä hevosväen ajatusmaailman kääntäminen ongelmasta voitoksi on ollut oleellinen osa tämän työn tuloksia.

Tehokkaan kompostointiprosessin ja sen mahdollisuuksien ymmärtäminen hevosen lannan käsittelyssä vahvistaa toimivan lantaketjun onnistumista. Muun muassa viljanviljelijöiden keskuudessa pelätty hukkakaura tuhoutuu rumpukompostorissa. Kompostointi toteutetaan hallitusti sille erikseen suunnitellussa tilassa, jolloin ravinteiden liukenemista ei pääse tapahtumaan. Hevosenlannan jatkohyödyntäminen lannoitteena on kemiallisten lannoitteiden hinnan nousun myötä kannattavaa. Jätteen synnyn etusijajärjestyksen mukaisesti toimiminen on ympäristöystävällisen tallin toimintatapa. Tämän kestävän kehityksen toimintamallin sisäistämisessä oppilaitos on avainroolissa.

Rumpukompostori on iso investointi hevostallille. Prosessoitaessa patogeenivapaata maanparannuskompostia, voidaan prosessista muodostuva hukkalämpö kerätä talteen ja hyödyntää lämpöenergiaksi. Noin kaksi kolmasosaa lämpöpumpun tuottamasta lämmöstä on uusiutuvaa energiaa ja kolmasosa tuotetusta lämmöstä tulee lämpöpumpun käyttämästä sähköstä. Jatkossa on mielenkiintoista tietää Hingunniemen kompostorin tuottaman lämpöenergian todellinen määrä. Kapasiteetti on mitoitettu niin, että se lämpöenergia mikä prosessia häiriintymättä saadaan talteen, kerätään ja hyödynnetään. Varalämmitys on turvattu kaukolämmöllä.

Energiatehokkaiden ja ympäristöystävällisten ratkaisujen toteuttaminen vaatii huolellista suunnittelutyötä. Kuitenkin jo pienillä muutoksilla saadaan aikaan kestävää kehitystä tukevia toimintamalleja. Euroopan unionin ympäristöpolitiikan keskeiset tavoitteet ovat jalkautuneet Suomen ympäristöpolitiikkaan Kataisen I hallitusohjelman myötä. Hallituksen tavoitteena on kehittää Suomesta ympäristöosaamisen, puhtaan teknologian, kestävän luonnonvarapolitiikan hiilineutraali yhteiskunta. Ympäristölainsäädäntöä säädetään näiden tavoitteiden mukaisesti ja hevossektorillakin on syytä pysähtyä ympäristöasioiden pariin.

\section{Kirjallisuus}

Asetus maataloudesta peräisin olevien nitraattien vesiin pääsyn rajoittamisesta. 931/2000.

Valtionneuvosto. [Viitattu 19.8.2012]. Saatavissa: http://www.finlex.fi/fi/laki/alkup/2000/20000931

Direktiivi vesien suojelemisesta maataloudesta peräisin olevien nitraattien aiheuttamalta

pilaantumiselta. Euroopan yhteisöjen neuvosto. 91/676/ETY. [Viitattu 19.8.2012]. Saatavissa: http://eurlex.europa.eu/LexUriServ/LexUriServ.do?uri=DD:15:10:31991L0676:FI:PDF.

Airaksinen. S. 2006. Bedding and Manure Management in Horse Stables. Its Effect on Stable Air Quality, Paddock Hygiene and the Compostability and Utilization of Manure. Kuopio: Korpijyvä.

Halinen, A., Tontti, T. 2004. Laitoskompostien laadun parantaminen kypsytystä tehostamalla. Helsinki: Data Com Finland Oy.

Jäteasetus. 1390/1993. Finlex. Lainsäädäntö. [Viitattu 19.8.2012]. Saatavissa: http://www.finlex.fi/fi/laki/smur/1993/19931390.

Jätelaki. 1072/1993, 14 §. Finlex. Lainsäädäntö. [Viitattu 19.8.2012]. Saatavissa: http://www.finlex.fi/fi/laki/ajantasa/1993/19931072. 
Lannoitevalmistelaki. Finlex. Lainsäädäntö. [Viitattu 19.8.2012]. Saatavissa: http://www.finlex.fi/fi/laki/alkup/2006/20060539.

Maaseutuvirasto: Maatalouden ympäristötuki. [verkkojulkaisu]. [Viitattu 6.12.2013]. Saatavissa: http://www.mavi.fi/fi/index/viljelijatuet/maataloudenymparistotuki.html.

Pesonen, I., Virtanen, H. \& Jansson, H. 2008. Hyvinvoiva turvallinen ja ympäristöystävällinen talli - opas vastuulliseen tallitoimintaan. Forssa: Painotalo Auranen

Rantala, T \& Viljakainen A-L. Esiselvitys maa- ja hevostalouden sivutuotteiden hyödyntämismahdollisuuksista Pohjois-Savossa: Nurmirehu, maatalousmuovit, hevosenlanta, olki. Epäkurantin nurmirehun ja hevosenlannan hyödyntäminen energiana -hankkeen loppuraportti. [Viitattu 11.9.2012]. Saatavissa:

http://portal.savonia.fi/img/amk/sisalto/teknologia_ja ymparisto/ymparistotekniikka/HEINAPAALI Esiselvi tysraportti_1.pdf

Soininen, H., Mäkelä, L., Äikäs, V. 2010. Ympäristöasiat osana hevostallien kannattavuutta. Mikkeli. Kopijyvä Oy.

Ympäristönsuojelulaki. 86/2000. Lainsäädäntö. [Viitattu 19.8.2012]. Saatavissa:

http://www.finlex.fi/fi/laki/ajantasa/2000/20000086

Ympäristönsuojeluasetus. 169/2000. Lainsäädäntö. [Viitattu 19.8.2012]. Saatavissa:

http://www.finlex.fi/fi/laki/ajantasa/2000/20000169.

Valtioneuvoston asetus jätteen polttamisesta. 362/2003. Lainsäädäntö. [Viitattu 21.8.2012]. Saatavissa: http://www.finlex.fi/fi/laki/alkup/2003/20030362. 